\title{
Acquiring Ventilators: Fighter Planes without High-octane Fuel and Pilots: Indian Perspective in COVID Era
}

\author{
Richa Aggarwal ${ }^{1}$, Anjan Trikha ${ }^{2}$
}

\begin{abstract}
During this coronavirus disease-19 (COVID-19) pandemic, all the countries are emphasizing on procurement of more and more sophisticated machineries for the intensive care unit (ICU) like ventilators. But do all countries have to follow the same? The requirements are different for low- and middle-income countries like India, which are resource limited. The ventilators require oxygen supply and manpower to function which are deficient in these countries. These countries might do well only by procurement of oxygen delivery machinery, as most of the patients of COVID require oxygen only. Only approx. Five percent of COVID-19 patients require ventilators. Moreover, the patients on ventilators have high mortality. Thus, low-resource countries need to redefine their priority as to how to utilize their resources. This manuscript emphasizes the need for the same.

Keywords: COVID-19, Oxygen supply, Ventilator.

Indian Journal of Critical Care Medicine (2020): 10.5005/jp-journals-10071-23525
\end{abstract}

Sir,

Coronavirus disease-19 (COVID-19) pandemic is expanding, and there is a steady increase in the number of infected cases daily. All the nations are trying to tackle this pandemic to their best capabilities. Learning from each other's experiences, the nations where peak is still expected like India are preparing for the worst. The emphasis is on strengthening the health infrastructure and acquisition of healthcare machinery. Intensive care units (ICUs) are being expanded in non-ICU areas, and efforts are being made to acquire more and more fancy equipment, such as ventilators, ECMO machines, hemodialysis machines, etc. Out of these, "ventilator" has become a household word all over the world. The availability of vaccine and the presence of a ventilator are being considered as the "saviors" of human race during this pandemic. Vaccine availability is time bound, as the trials would have to go through rigorous tests, so the spot light is on ventilators! There are countries that are donating ventilators to the developing world to show solidarity and as a good will gesture in this time of stress. ${ }^{1}$ Many countries are trying to buy and accumulate a large number of ventilators at escalated prices, and India is not lagging behind! On April 9, the Health Ministry informed that India had placed orders for 49,000 ventilators anticipating that the COVID virus-infected patients would survive due to them. But is this really true?

It is to be understood that not all COVID-19 patients become critically ill. According to the available literature, nearly $80 \%$ of patients infected with COVID-19 have mild to moderate disease. ${ }^{2}$ Out of the rest $20 \%$ who develop severe disease, $5-12 \%$ of patients become critically ill and require ICU admission and mechanical ventilation. Rest can be managed with supportive treatment, simple oxygen therapy, and careful monitoring. Moreover, the mortality rate of patients managed on ventilators is quite high. Early reports from China and New York found mortality rate more than $85 \%$ in patients on ventilators; now data from UK report around $50 \%$ mortality, ${ }^{5}$ all from countries that have robust healthcare system. These figures compelled some critical care physicians to question the use of ventilators for COVID-19 patients.
${ }^{1}$ Department of Critical and Intensive Care, JPN Apex Trauma Centre, All India Institute of Medical Sciences, New Delhi, India

${ }^{2}$ Department of Anaesthesiology, Critical Care and Pain Medicine, All India Institute of Medical Sciences, New Delhi, India

Corresponding Author: Anjan Trikha, Department of Anaesthesiology, Critical Care and Pain Medicine, All India Institute of Medical Sciences, New Delhi, India, Phone: +91 9810977901, e-mail: anjantrikha@gmail. com

How to cite this article: Aggarwal R, Trikha A. Acquiring Ventilators: Fighter Planes without High-octane Fuel and Pilots: Indian Perspective in COVID Era. Indian J Crit Care Med 2020;24(8):735-736.

Source of support: Nil

Conflict of interest: None

On the other hand, what about oxygen therapy? Are we well equipped to provide oxygen in peripheral settings? The answer is not lucid. Many hospitals in primary settings do not have even continuous oxygen supply. There have been reports of mortality in patients due to unavailability of oxygen! If true, it is very unlikely that the availability of ventilators could have prevented these deaths. Literally, ventilators are not the primary need; first is the need of uninterrupted supply of medical gases especially oxygen and the second is the infrastructure and human resources.

The infrastructure in terms of dedicated ICUs does not exist in all hospitals. The question is where will the ventilators work. However, oxygen manifold and pipelines exist in tertiary-level hospitals, and oxygen therapy can be easily provided in the wards or emergency areas without the need of ICUs. In remote primary health centers, oxygen can be delivered through oxygen cylinders. Primary health centers are the cornerstone of rural healthcare and backbone of health infrastructure in India. Instead of referring all the patients to tertiary hospitals, primary hospitals should be more equipped with basic oxygen cylinders and monitoring system.

Furthermore, managing patients on ventilator require manpower, a team of experts which is not adequately available

() The Author(s). 2020 Open Access This article is distributed under the terms of the Creative Commons Attribution 4.0 International License (https://creativecommons. org/licenses/by-nc/4.0/), which permits unrestricted use, distribution, and non-commercial reproduction in any medium, provided you give appropriate credit to the original author(s) and the source, provide a link to the Creative Commons license, and indicate if changes were made. The Creative Commons Public Domain Dedication waiver (http://creativecommons.org/publicdomain/zero/1.0/) applies to the data made available in this article, unless otherwise stated. 
in resource-limited settings. Latest available statistics shows that $40 \%$ of World Health Organization (WHO) Member States have less than 1 physician per 1,000 population which is the WHO norm. ${ }^{6}$ The doctor population ratio in India is 1:1456 which is far below the standards.

It is prudent to mention that the need is not ventilators although it sounds attractive. Developing countries like India should shift their focus from procuring more and more ventilators to provision of oxygen supply. The expenditure meant for ventilators can be invested for other more important requirements such as continuous oxygen supply and personal protective equipment for healthcare workers. Moreover, let the developed nations ensure availability of medical gases, trained man power, and then provide ventilators in that order. Otherwise, these sophisticated machines would lie in a store of a district hospital till they are condemned after a decade.

\section{References}

1. US to donate ventilators to India to fight coronavirus: Donald Trump. The Economic Times. Politics and Nation. 2020, May 16. Available from https://economictimes.indiatimes.com/news/politics-and-nation/ donald-trump-promises-ventilators-to-india-says-both-countries- working-together-on-vaccine/articleshow/75768350.cms?from $=\mathrm{mdr}$ (accessed May 30, 2020).

2. Wu Z, McGoogan JM. Characteristics of and important lessons from the coronavirus disease 2019 (COVID-19) outbreak in China: Summary of a report of 72314 cases from the Chinese Center for Disease Control and Prevention. JAMA 2020;323(13):1239-1242. DOI: 10.1001/ jama.2020.2648.

3. Ruan Q, Yang K, Wang W, Jiang L, Song J. Clinical predictors of mortality due to COVID-19 based on an analysis of data of 150 patients from Wuhan, China. Intensive Care Med 2020;46(5):846-848. DOI: 10.1007/s00134-020-05991-x.

4. Richardson S, Hirsch JS, Narasimhan M, Crawford JM, McGinn T, Davidson KW, et al. Presenting characteristics, comorbidities, and outcomes among 5700 patients hospitalized with COVID-19 in the New York city area. JAMA 2020;323(20):2052-2059. DOI: 10.1001/ jama.2020.6775.

5. Intensive Care National Audit and Research Centre: ICNARC Report on COVID-19 in Critical Care. 2020. Available at: https://www.icnarc. org/DataServices/Attachments/Download/cbcb6217-f698-ea11912500505601089b Accessed May 30, 2020.

6. Density of Physicians (Total Number per 1000 Population, Latest Available Year), Global Health Observatory (GHO) Data. Situation and Trends. Available from: http://www.who.int/gho/health_workforce/ physicians_density/en/ [Last accessed on 4/6/2020]. 